\title{
Extravasación intraabdominal de líquido posterior a artroscopía de cadera: Reporte de un caso
}

\author{
Intraabdominal fluid extravasation after hip arthroscopy: \\ Case report
}

Tomas Cerda G. ${ }^{1}$, Nicolás García M.D. ${ }^{2}$, Loreto Mosqueira M.D. ${ }^{3}$

\begin{abstract}
Intraabdominal fluid extravasation (IAFE) is a rare complication of hip arthroscopy which has a wide range of clinical presentations, from mild abdominal distention to abdominal compartment syndrome and cardiorespiratory arrest. There are few detailed reports of cases in literature, therefore, considering risk factors, high pathological suspicion and training in ultrasound are key points to prevent complications and health costs. In this report, the case of a 29 year old male patient with severe abdominal pain during the immediate postoperative period of an arthroscopic hip surgery is presented, which led to a review of the literature on the subject.
\end{abstract}

\section{RESUMEN}

La extravasación intraabdominal de líquido es una complicación poco frecuente de la artroscopia de cadera que presenta un amplio rango de manifestaciones clínicas, desde leve distensión abdominal hasta síndrome compartimental y paro cardiorrespiratorio. Hay escasos reportes de casos en la literatura, por lo que la alta sospecha considerando factores de riesgo y el ultrasonido son claves para prevenir sus complicaciones y costos asociados. En este reporte, se presenta el caso de un paciente masculino de 29 años con dolor abdominal intenso durante el postoperatorio inmediato de una artroscopia de cadera, lo que llevó a una revisión de la literatura sobre el tema.

\section{Key words:}

Intrabdominal, extravasation, arthroscopy, hip
Palabras clave: intraabdominal, extravasación, artroscopia, cadera

Interno, Facultad de Medicina, Pontificia Universidad Católica de Chile.

Residente, División de Anestesiología, Facultad de Medicina, Pontificia Universidad Católica de Chile.

Anestesióloga, División de Anestesiología, Facultad de Medicina, Pontificia Universidad Católica de Chile.

Fecha de ingreso: 17 de febrero de 2020

Fecha de aceptación: 22 de junio de 2020

Abdominal fluid after hip arthroscopy

\section{ORCID}

https://orcid.org/0000-0003-3385-9543

Correspondencia:

Loreto Mosqueira

loretomosqueirap@gmail.com 


\section{Glossary of terms:}

IAFE: Intraabdominal fluid extravasation

ASA: American society of anesthesiologists

VAS: Visual analog scale

CT: Computed tomography

\section{Introduction}

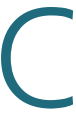

omplications secondary to hip arthroscopy are rare[1]. Intraabdominal fluid extravasation (IAFE), is a little known complication, despite being reported by anesthetic and trauma literature[2],[3]. Its clinical presentation ranges from abdominal distension and nausea, to severe cases such as abdominal compartment syndrome and cardiac arrest.

In this report, the case of a 29 year old male patient with severe abdominal pain during the immediate postoperative period of an arthroscopic hip surgery is presented, which led to a review of the literature on the subject. Informed patient consent was obtained.

\section{Case description}

Male, 29 years old (height: $1.88 \mathrm{~m}$, weight: 83 $\mathrm{kg}$, Body mass index: $23.5 \mathrm{~kg} / \mathrm{m}^{2}$ ), American society of anesthesiologists (ASA) category II, with history of mood disorder in treatment with Lamotrigine $200 \mathrm{mg} /$ day. With no previous surgical history and New York Heart Association Functional Capacity category I. With diagnosis of Femoro-acetabular Impingement of the left hip, programmed for elective hip arthroscopy.

Standard monitoring was performed with Electrocardiogram, saturometry and non-invasive blood pressure.

Spinal anesthesia was performed under sedation with $3 \mathrm{mg}$ of midazolam. Single puncture, L3-L4 with a Whitacre $25 \mathrm{G}$ trocar was made in right lateral decu-

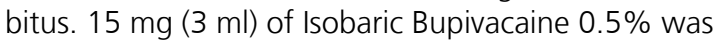
injected and remained lateralized for $10 \mathrm{~min}$, then positioned in supine position, resulting in a T10 level on the left side.

Oxygen was supplemented by venturi mask (8 liters/min) and target-controlled infusion propofol was titrated up to $2.5 \mathrm{ug} / \mathrm{ml}$ concentration in site effect (Marsh Model) as intraoperative sedation.

Once placed on the easel, traction was performed on the left leg until distraction of the joint space, confirmed with $X$ rays for a total of 100 minutes. Through anterolateral and anterolateral accessory portals, acetabuloplasty was performed with Osteoraptor 2,3 loop type suture. Microfracture was performed every 3-4 mm, with adequate bleeding control.

Irrigation was performed with standard solution (Ringer lactate plus epinephrine in concentration 1 $\mathrm{mg} / \mathrm{l})$, completing 22 liters.

Anesthetic management without incidents, stable hemodynamics without VAD requirements or desaturation episodes.

During the immediate postoperative period, the patient complained of infraumbilical abdominal pain, of dull character, intensity 10/10 of the Visual analog scale (VAS), associated with rectal pushing sensation. Vital signs were within normal range, heart rate 80 bpm, blood pressure 118/74, saturation 99\% with $\mathrm{FiO}_{2} 28 \%$, however the patient was agitated and sweaty. The abdomen was depressible, sensitive with slight resistance to palpation in the inferior hemiabdomen, without peritoneal signs. A bolus of $3 \mathrm{mg}$ of intravenous Morphine was administered, titrating according to response, administering a total of $20 \mathrm{mg}$ in $40 \mathrm{~min}$ with little pain reduction. An abdominal ultrasound was performed by the anesthesiologist that showed moderate bladder distension, without evidence of free intraperitoneal fluid. Foley bladder catheterization was indicated, without pain reduction.

The patient was evaluated by the surgery team, who requested a Computed-tomography scan (CT) of the abdomen and pelvis, which showed recent postsurgical changes in relation to the left coxofemoral joint, identifying intermuscular edema in the proximal left thigh and gluteal region, in addition to marked edema in subcutaneous cellular tissue and some gas bubbles of anterior disposition between the proximal quadriceps. There was a slight lateralized left edema in the presacral and extraperitoneal space of the pelvis, especially adjacent to the ipsilateral iliac vessels, without identifying collections or images suggestive of hematomas (Figure 1).

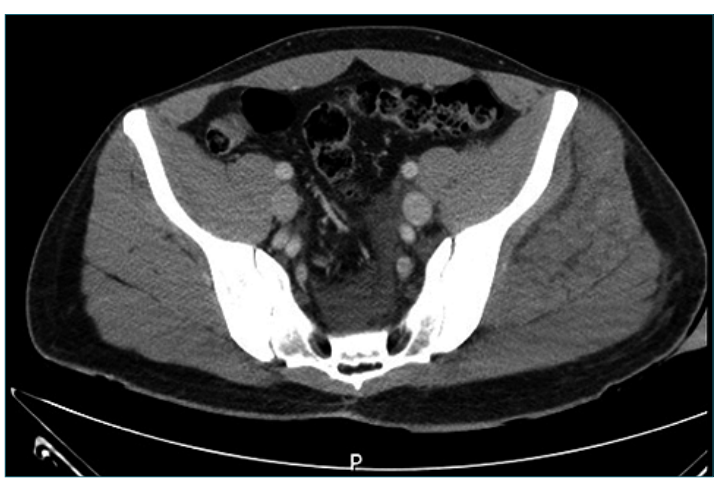

Figure 1. Computed-tomography scan (CT). 
After de diagnosis of IAFE, the patient evolved with spontaneous decrease in abdominal pain and was discharged of the post anesthetic recovery unit after 3 hours.

\section{Discussion}

Extravasation of fluid is a known phenomenon of hip arthroscopy. In asymptomatic patients, there is an extravasation of an average of 1.13 to $3.06 \mathrm{~L}$, whose most common location is the thigh $(100 \%)$, gluteus $(82.5 \%)$ and intra and retroperitoneal space (47.5\%)[4]. IAFE is caused by filtration of the irrigation solution towards the extra-articular tissues, passing through the iliopsoas muscle with its subsequent intra-abdominal accumulation.

In 2012 the "Multicenter Arthroscopy of the Hip Outcomes Research Network" (MAHORN) concluded, after reviewing more than 25,000 cases, that the incidence of symptomatic IAFE after hip arthroscopy was $0.16 \%[5]$.

In a prospective observational study published in Anesthesia \& Analgesia, Haskins et al. enrolled one hundred patients undergoing elective hip arthroscopic, in which abdominal ecotomography with FAST protocol was performed (pre- and post-operatively) by a trained anesthesiologist, finding an IAFE overall incidence of $16 \%[6]$, a hundred times greater than that reported by MAHORN group.

Identified risk factors for the development of symptomatic IAFE are: high intra-articular pressure generated by the irrigation solution (determined by the height of the water column), iliopsoas tenotomy, prolonged surgical time[7] and female sex[8] due to pelvic anatomical differences and greater elasticity of the tissue.

In this case, we do not know the exact height of the water column neither the intraarticular pressure, no iliopsoas tenotomy was performed, and the total volume of irrigation solution was 22 liters, $37 \%$ more than the average reported by Haskins study[6].

IAFE symptomatology is variable, from mild symptoms such as nausea or abdominal distension to abdominal compartment syndrome and cardiorespiratory arrest[2]. There have been 9 case reports in literature with extensive details on the progression of this clinical situation. The most common clinical manifestations are: abdominal distension (89\% of cases), hypothermia (56\%), hypotension (33\%) and metabolic acidosis (33\%)[4]. Only one case was detected in the middle of surgery, 3 in the end, 4 when the surgical fields were removed and one 4 hours postoperatively[4].

Regarding the use of ultrasound, its performance for the diagnosis of IAFE has a sensitivity of $64-98 \%$ and specificity of $86 \%-100 \%$ for a trained operator[9]. It is important to consider the incorporation of ecotomography courses in anesthesiology programs, as a safe, non-invasive, relatively inexpensive and easily available technique, however, requiring training and continuous practice. In 2013, Terkawi AS et al., published a review regarding the role of ultrasonography in anesthetic practice in which they suggest that training with ultrasound should be part of every anesthesiology program[10].

The implications of IAFE can be evaluated from the study of Haskins et al., where patients were associated with greater increase in pain assessment score during their stay in the anesthetic recovery unit ( $p$ $=0.002$ ) and higher opiate requirements, although this last was not statistically significant. Regarding the time they remained in this unit, no differences were found[6]. However, the study was not originally planned for that (lack of study power), making us think about the possibility that this complication could be related to greater consumption of opioids, longer recovery stay and greater requirements for examinations and interconsultations, which translates into higher health costs associated.

Diagnostic and treatment algorithms have been developed, which emphasize the prior identification of risk factors and intraoperative findings[4].

In conclusion, the intraabdominal extravasation of fluid after hip arthroscopy is a rare complication whose spectrum of clinical manifestation is highly variable, from asymptomatic to death risk situations. There are few detailed reports of cases in literature so it is extremely important to take it into account within the possible complications of this type of surgery. It is also important to consider the risk factors to develop this event and establish preventive measures and early awarness of the situation. Finally, with regard to diagnosis, in addition to the clinical suspicion, it is important to incorporate training in the use of ultrasound in anesthesiology programs for the early detection and thus avoid health costs and implications that can be fatal for the patient. 


\section{References}

1. Ilizaliturri VM Jr. Complications of arthroscopic femoroacetabular impingement treatment: a review. Clin Orthop Relat Res. 2009 Mar;467(3):760-8. https:// doi.org/10.1007/s11999-0080618-4 PMID:19018604

2. Sharma A, Sachdev H, Gomillion M. Abdominal compartment syndrome during hip arthroscopy. Anaesthesia. 2009;64:567-569., Ladner B, Nester K, Cascio B. Abdominal fluid extravasation during hip arthroscopy. Arthroscopy. 2010;26:131-5.

3. Ladner B, Nester K, Cascio B. Abdominal fluid extravasation during hip arthroscopy. Arthroscopy. 2010 Jan;26(1):1315. https://doi.org/10.1016/j. arthro.2009.09.015 PMID:20117638

4. Ekhtiari S, Haldane CE, de Sa D, Simunovic N, Ayeni OR. Fluid Extravasation in Hip Arthroscopy: A Systematic Review. Arthroscopy. 2017 Apr;33(4):873-80. https://doi.org/10.1016/j.

arthro.2016.11.009

PMID:28109644

5. Kocher MS, Frank JS, Nasreddine AY, Safran MR, Philippon MJ, Sekiya JK, et al. Intra-abdominal fluid extravasation during hip arthroscopy: a survey of the MAHORN group. Arthroscopy. 2012 Nov;28(11):1654-1660. e2. https://doi.org/10.1016/j. arthro.2012.04.151 PMID:22989716

6. Haskins SC, Desai NA, Fields KG, Nejim JA, Cheng S, Coleman SH, et al. Diagnosis of Intraabdominal Fluid Extravasation After Hip Arthroscopy With Point-of-Care Ultrasonography Can Identify Patients at an Increased Risk for Postoperative Pain. Anesth Analg. 2017 Mar;124(3):7919. https://doi.org/10.1213/ ANE.0000000000001435 PMID:27551733

7. Sampson TG. Complications of hip arthroscopy. Clin Sports Med. 2001 Oct;20(4):8315. https://doi.org/10.1016/
S0278-5919(05)70288-X

PMID:11675890

8. Hinzpeter J, Barrientos $C$, Barahona M, Diaz J, Zamorano A, Salazar A, et al. Fluid Extravasation Related to Hip Arthroscopy: A Prospective Computed Tomography-Based Study. Orthop J Sports Med. 2015 Mar;3(3):2325967115573222. https://doi. rg/10.1177/2325967115573222 PMID:26665027

9. Körner M, Krötz MM, Degenhart C, Pfeifer KJ, Reiser MF, Linsenmaier U. Current role of emergency US in patients with major trauma. Radiographics. 2008 Jan-Feb;28(1):225-42. https:// doi.org/10.1148/rg.281075047 PMID:18203940

10. Terkawi AS, Karakitsos D, Elbarbary M, Blaivas M, Durieux ME. Ultrasound for the anesthesiologists: present and future. ScientificWorldJournal. 2013 Nov;2013:683685. https://doi. org/10.1155/2013/683685 PMID:24348179 